\title{
A Study on the Learning Satisfaction and Work Utilization of the Teacher Safety e-Learning
}

\author{
Mi Hwa Song and Tea In Han
}

\begin{abstract}
Study about teacher safety education must be carried out in a concrete and statistical manner for all accidents surrounding the school. The purpose of this study is to identify the changes in learning satisfaction and job utilization of e-learning based teacher safety education that they perceive, and to utilize it more effectively in real life and work for the safety of school. The results of this study suggest the following conclusions. First, it is necessary to develop more specific and systematic safety education programs and curriculum to improve the quality level of e-learning based teacher safety education and learning satisfaction and to utilize effective work. Second, because there is a difference between the satisfaction of learning and the utilization of work according to the work area and work experience of the teacher, various and detailed programs should be developed and continuously provided. Third, it is necessary to expand the research result for comparison between classroom safety education and safety e-learning so that the evaluation about the effectiveness of learning satisfaction and job utilization. Fourth, safety education of school encountered with situation that most of the teachers learn safety lecture through distance education, and they teach it to the students by the walk-through safety education. So teacher safety education should include experienced and hand on subdivided courses because teacher is responsible for student safety education.
\end{abstract}

Index Terms-E-learning, learning satisfaction, safety education, teacher safety education, work utilization.

\section{INTRODUCTION}

\section{A. Research Background and Necessity}

Safety closely link to life, and in order to secure the safety of individuals and society, it is necessary to complete safety facilities and systems, and to carry out the necessary education to conduct daily life safely.

Safety education means to understand the knowledge necessary for safety in daily life or specific activities through means of education and to form a habit of respecting the other person and maintaining a safe and healthy life [1].

When the educational activities of the home and the educational institution are carried out for effective safety education because safe life is habituated and various effects can be expected [1]. Teachers of school must learn the overall contents of prevention and preparation of accidents as well as

Manuscript received July 4, 2019, revised August 11, 2019.

Mi Hwa Song is with the Department of e-Learning Graduate School, National Open University, Seoul, Korea. She is also with the Balgok Elementary School, Korea (e-mail: angelhwa@korea.kr).

Tae In Han is with the Department of e-Learning Graduate School, National Open University, Seoul, Korea (correspondence author; e-mail: hanten55@daum.net, hanten55@knou.ac.kr). response and recovery of actual accidents. In case of Korea, Ministry of Education launched a one-year period safety education from November 11, 2014 to February 28, 2018 at the government level, because of the big cruise ship accident of the April 15, 2014 in Korea, and teacher should learn it every three years thereafter. All the teachers of educational organization required to take safety education that is consist of at least three courses of the seven domain on safety area, it include at least 15 hours training by legal obligations [2].

The distance e-learning has the advantage that can lead to self-directed learning of learners, and it can easily manage the latest contents of for operation and management. The analysis of the learning satisfaction and the utilization of the e-learning-based teacher safety education should need for continuous development of the safety education and subdivided courses that take into consideration of meeting the requirements of the time.

This study planned to build a foundation of safety management system in school and operation of normal curriculum, furthermore it contributes to protect the lives and property of individuals, and to realize a happy school for students' dreams and hopes.

\section{B. Research Purpose}

The purpose of this study is to investigate the satisfaction of teachers on e-learning based safety education, whether there are a difference between learning satisfaction and job utilization according to general characteristics of teachers such like gender, age, work area and experience. The other purpose of this study is to clarify the difference of learning satisfaction and work utilization according to general characteristics of research subjects and the influence of e-learning on the utilization of work after safety education. It used as basic data for the development of diverse and detailed programs to utilize the work. Evaluating the satisfaction of an e-learning-based safety education program for teacher, including the evaluation of teacher, will be useful in itself and will inform the success of the education. It can also provide educated practitioners and decision-makers with a variety of important information to make decisions about existing or future safety education. For this purpose, three variables of learning contents, system, and operation management affecting learning satisfaction are selected through analysis of prior research on e-learning. Through previous studies related to the utilization of work, analysis work connection, protection of accidents, guidance of safety activities, and changes in safety consciousness.

In this paper, the relationship between the variables that have the effectiveness on the learning satisfaction of the 
e-learning based teacher safety education, and it is also aimed to make more efficient e-learning based on teacher safety education in the future and effectively utilize it for real life and work for the safety after finishing the safety education.

\section{Research Method}

In order to achieve the purpose, first, this study explores government policy documents, research reports and various data from the Ministry of Education. The pre-research paper and document review performed to design the survey items. Second, this research conducts the survey about learning satisfaction and work utilization after finishing of e-learning based teacher safety education. Third, this research collects the data and analyzes statistically for the results by the 72 teachers from the Gyeonggi Provincial Office of Education.

\section{PRECEDENT RESEARCH}

\section{A. Teacher Safety Education}

\section{1) Pre-research for teacher safety education}

\begin{tabular}{|c|c|}
\hline 7 categories & 25 domains \\
\hline \multirow{3}{*}{ living safety } & facility and product usage safety \\
\hline & physical activity safety \\
\hline & prevention of kidnap and missing child \\
\hline \multirow{5}{*}{ traffic safety } & pedestrian safety \\
\hline & bicycle safety \\
\hline & motorcycle safety \\
\hline & automobile safety \\
\hline & public transportation safety \\
\hline \multirow{5}{*}{ prevention of violence } & school violence \\
\hline & sexual violence \\
\hline & child abuse \\
\hline & suicide \\
\hline & family violence \\
\hline \multirow{2}{*}{$\begin{array}{l}\text { prevention of drug } \\
\text { and computer addiction }\end{array}$} & drug addiction \\
\hline & cyber addiction \\
\hline \multirow{3}{*}{ disaster safety } & fire \\
\hline & community disaster \\
\hline & natural disaster \\
\hline \multirow{4}{*}{ occupational safety } & job safety consciousness \\
\hline & industrial disaster prevention \\
\hline & occupational disease \\
\hline & occupational safety management \\
\hline \multirow{3}{*}{ first aide } & understand of first aide \\
\hline & cardiopulmonary resuscitation \\
\hline & first aide by situation \\
\hline
\end{tabular}

A faculty member is a collective term for teachers and staff who are responsible for the education of students or the administration of the school in each class, regardless of the type and name of employment. Education program of school safety developed by safety experts and teachers according to the level of growth for K12 students, and it used for students and teachers differently at the viewpoint of learning and teaching aspects. This program consist of 7 categories, 25 domains and 52 items [2]. The seven categories are living safety, traffic safety, prevention of violence, prevention of drug and computer addiction, disaster safety, occupational safety and first aide, the details are as shown in "Table I".

\section{2) Case for teacher safety education}

All faculty and staff are subject to legal duties and evaluation for safety education [3]. On November 16, 2014, all members of the school and educational institute will be required to submit a report to the Ministry of Education, Science, and Technology. The safety education that reflects the above started to take one mandatory duty until February 28, 2018. After that, every three years, it would be compulsory for 15 hours or more including 3 training courses, such as collective face to face individual training or group training, on-line remote training, and self-training in the institute. The experimental group in this study are 72 teachers of the Gyeonggi Provincial Office of Education who have completed teacher education of e-learning.

\section{B. Learning Satisfaction}

\section{1) Learning content satisfaction}

Satisfaction with learning contents that designed and developed so that effective learning can achieve by using e-learning-based digital technology to achieve educational goals or improve performance is important for education. Learning contents are the most important concern of learners because content delivery is the key in e-learning.

The fact that learning content affects learning satisfaction has been proven through many studies for a long time and related items include relevance, timeliness, fulfillment, reliability, systematical structure, accuracy, usability and up-to-date. Although learning contents were mainly evaluated based on accuracy, gradually increasingly accurate information was not always useful, and as the perception increased that the learners' utilization aspect should be considered, the contents of the learning began to be treated in terms of 'suitability' and 'relevance' respectively [4].

The quality of learning subject enhanced when it apply with to the e-learning environment because of the relevance and flexibility of the contents. It also present as the measurement elements of the learning contents, and the meaningful learning experience provided through the composition of the designed course and the learning contents as a way to enhance learning. Especially, in e-learning, the content of learning is an important quality factor that encompasses various factors related to teaching and learning method by encompassing methods and strategies.

\section{2) System satisfaction}

System satisfaction means the satisfaction of technical level as the accuracy and operational efficiency of the information processing system. System satisfaction metrics include hardware and software aspects, web pages, interfaces, accessibility, convenience, speed, ease of use, functionality, reliability, flexibility, and screen readability.

System satisfaction can have a profound effect on learner satisfaction. In the screen design of the e-learning system, satisfaction is achieved through systematic factors such as 
characteristic designation that to increase learner readability, graphic design to help understanding meaning of content, animation design which helps movement process of understanding that learner can pull it out. It shows that e-learning repetition purchase and usage frequency are different according to the physical conditions such as environmental factors of the system [5].

Because e-learning is controlled by the learners themselves, learning can be easily abandoned if the optimal environment is not provided for effectively and efficiently. Therefore, the speed, stability, accessibility, and ease of the system environment will greatly affect learning progress so that e-learning-based learners can smoothly proceed without dropping or giving up [6]. In the case of e-learning, the system stabilized compared to the time when there were many technical problems in the internet connection speed and system stability, and in the environment where the e-learning was used, the system satisfaction of the learner decreased in the relative importance of the influence on the success of the system [7]. However, in the e-learning system on the web, stability, speed, and persistence of the system are still a major factor [8], [9].

\section{3) Operational management satisfaction}

Operational management satisfaction means satisfaction with all kinds of support provided to learners of information systems [10]. The learner evaluates not only the quality of the contents of education, which is a direct part, but also a series of administrative support, counseling support, affection of kindness and support of education institution personnel, and natural interaction. The results of the evaluation provide appropriate feedback on the quality and progress of the management personnel. This is a post evaluation based on experience with the service provided by the learner, which is the reactivity, reliability, persistence, contact, and emotional consideration that the learner perceives during the use [11].

It also means the efforts of the learner management to form and maintain individual relations with the learner. It is the management and operation of the learner learning process including the learning facilitation strategy of the instructor and the supporting learning tool. It is a very important part to manage the learner subjective evaluation level.

Students who feel dissatisfied with the e-learning operation management use other e-learning systems or communicate their opinions about dissatisfaction to other learners. This implies that e-learning satisfaction can have a larger ripple effect than the learner's satisfaction according to traditional teaching methods [11].

\section{4) Work utilization after teacher safety education}

Teachers' safety education centered on 'safety education 7 areas', but it needs to cope with not only accident prevention but also situations that need recovery. We need to educate. Staff members should teach the overall contents of prevention and preparation of accident as well as response and recovery of actual accident [12]. Staff safety education included not only work related contents such as facility management and attending school management, but also contents to know as a living person. The degree of utilization of work refers to the degree to which safety related work carried out, such as job-relatedness, safety accident prevention, safety guidance, change of safety consciousness, and experience of safety accident after staff safety education. The ability of the staff to perform their work is a comprehensive and abstract concept, which means the knowledge and technical attitudes involved and collectively referred to all tasks.

\section{5) Implications}

All the members of the school and the educational institute recognize the safety education of the staff not only as a legal obligation but also as an opportunity for the improvement of the real life and the effective utilization of the work for the safety of the staff themselves and are actively educated. You should be interested. In addition to the implementation of teacher safety education, it is necessary to strengthen the recognition of the importance of the performance and efficiency of the staff safety education in the future. Research on the importance recognition and subjective needs of e-learning-based safety education evaluation of the staff needed. It is necessary to establish a plan to increase the participation of staff members in safety education by confirming diverse educational needs according to the occupation type, job duty, and work experience of the staff. It is necessary to develop valid evaluation tools that can effectively evaluate the learning satisfaction and post-training utilization of e-learning-based staff safety education. The program developers and operators should evaluate the program in detail and systematically from the planning, development and implementation of the program, and evaluation factors according to the evaluation step, not the questionnaire for the temporary evaluation after the program implemented.

\section{RESEARCH ANALYSIS}

\section{A. Research Model Design}

\section{1) Measuring tools}

The questionnaires of this study select from the previous studies and the reliability and validity verified and supplemented according to the study. The questions about the learning satisfaction of learning contents, system, and operation management are developed by some modified and supplemented measurement tools [13], [14].

First, this study select usability, achievement, systematic structure, appropriateness [15]. Second, the accessibility, speed, convenience, and screen readability selected for the system [16]. Third, quickness, aggressiveness, information power, reliability and interaction selected for operation management. The questionnaire about job utilization designed for self-confidence about safety related performance and structured items derived from previous research [17], [18]. As a result, the questionnaire of this study divided into 5 items of general characteristics, 14 items related to learning satisfaction, and 11 items related to work 
utilization. The details are as shown in "Table II".

\section{2) Experimental group}

The experimental persons group of this study are 72 teacher members of the Gyeonggi Provincial Office of Education who have completed teacher education of the basis of e-learning. When we look at the distribution of gender of 72 faculty members who are surveyed respondents, 28 $(38.9 \%)$ are males and $44(61.1 \%)$ are females.

In addition, $12(16.7 \%)$ of the teachers are in their $20 \mathrm{~s}, 27$ $(37.5 \%)$ of the teachers are in their 30 s, $22(30.6 \%)$ of the teachers are in their $40 \mathrm{~s}$ and $11(15.3 \%)$ of the teachers are in their $50 \mathrm{~s}$ or older. The practical teachers among experimental group of this study were 36 (50.0\%), and followed by local officials $(25.0 \%)$ and education officials $(23.6 \%)$, and others (1.4\%). Twenty - two (27.8\%) were between the ages of 6 and 10 years, and $8(11.1 \%)$ were over 21 years for carrier.

TABLE II: QUESTIONNAIRE CONTENTS

\begin{tabular}{|c|c|c|c|}
\hline \multicolumn{3}{|c|}{ Contents } & Variable name \\
\hline \multirow{5}{*}{$\begin{array}{c}\text { General } \\
\text { characteristic } \\
\mathrm{S}\end{array}$} & \multicolumn{2}{|c|}{ gender } & SEX \\
\hline & \multicolumn{2}{|c|}{ age } & AGE \\
\hline & \multicolumn{2}{|c|}{ Occupation } & JOB \\
\hline & \multicolumn{2}{|c|}{ Work experience } & CAR \\
\hline & \multicolumn{2}{|c|}{ Completion of safety education } & STU \\
\hline \multirow{14}{*}{$\begin{array}{l}\text { Learning } \\
\text { satisfaction }\end{array}$} & \multirow{5}{*}{ Learning contents } & $\begin{array}{c}\text { Learning content } \\
\text { availability }\end{array}$ & $\mathrm{C} 1$ \\
\hline & & Learning Contents & $\mathrm{C} 2$ \\
\hline & & $\begin{array}{l}\text { Learning contents } \\
\text { systematicity }\end{array}$ & $\mathrm{C} 3$ \\
\hline & & $\begin{array}{l}\text { Learning content } \\
\text { suitability }\end{array}$ & $\mathrm{C} 4$ \\
\hline & & Learning content Newest & $\mathrm{C} 5$ \\
\hline & \multirow{4}{*}{ system } & System accessibility & S1 \\
\hline & & System Convenience & S2 \\
\hline & & \begin{tabular}{|c|} 
System speed \\
\end{tabular} & S3 \\
\hline & & System screen readability & S4 \\
\hline & \multirow{5}{*}{$\begin{array}{l}\text { Operations } \\
\text { Management }\end{array}$} & $\underset{\text { Speed }}{\text { Operational management }}$ & M1 \\
\hline & & Active Management & M2 \\
\hline & & $\begin{array}{c}\text { Operational management } \\
\text { information }\end{array}$ & M3 \\
\hline & & $\begin{array}{c}\text { Operational management } \\
\text { reliability }\end{array}$ & M4 \\
\hline & & $\begin{array}{c}\text { Operational management } \\
\text { interaction }\end{array}$ & M5 \\
\hline \multirow{11}{*}{$\begin{array}{l}\text { Business } \\
\text { utilization }\end{array}$} & \multirow{2}{*}{\multicolumn{2}{|c|}{ Business Connectivity }} & L1 \\
\hline & & & L2 \\
\hline & Safety acc & dent experience & $\mathrm{T} 1$ \\
\hline & \multirow{6}{*}{\multicolumn{2}{|c|}{ Prevention of accidents }} & P1 \\
\hline & & & $\mathrm{P} 2$ \\
\hline & & & P3 \\
\hline & & & $\mathrm{P} 4$ \\
\hline & & & P5 \\
\hline & & & P6 \\
\hline & \multicolumn{2}{|c|}{ Safety map } & P7 \\
\hline & \multicolumn{2}{|c|}{ Safety consciousness change } & $\mathrm{R} 1$ \\
\hline \multicolumn{4}{|c|}{ Total 30questionaires } \\
\hline
\end{tabular}

\section{3) Research hypothesis}

The hypothesis of this study designed in order to identify the difference and influence of learning satisfaction and work utilization according to general characteristics of learners.

Research hypothesis 1. There is a difference in the learning satisfaction and the task utilization according to the general characteristics of the learners.

First, there is a difference in learning satisfaction and work utilization according to the age of the learners. Second, there is a difference in the satisfaction of learning and the utilization of work according to work area of learners. Third, there is a difference in learning satisfaction and work utilization according to work experience of learners.

Research hypothesis 2. Learning satisfaction of e-learning-based teacher safety education affects job utilization. First, the learning satisfaction of the e-learning based teacher safety education affects to the business connection. Second, the learning satisfaction of the e-learning based teacher safety education affects to the prevention from the accident. Third, the learning satisfaction of e-learning based teacher safety education affects to the safety consciousness change.

\section{4) Research model}

The purpose of this study is to investigate the difference of learning satisfaction and job utilization of e-learning based teacher safety education according to the age, work area, and work experience of teachers, and set it as a dependent variable. The study model is shown in "Fig. 1", by analyzing the influence of learning satisfaction and work utilization after finishing e-learning based teacher safety education on the influence of business connection, prevention from the accidents,

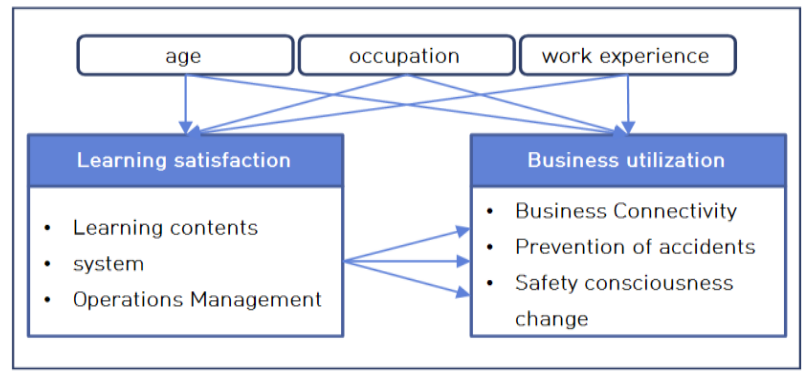

Fig. 1. Study on satisfaction and work utilization of e-learning based safety education for faculty and staff.

\section{B. Reliability Test of Variables}

\section{1) Independent variable reliability test}

The data of this study collected from 14 items related to learning satisfaction and 11 items related to work utilization in order to find out the variables affecting learning satisfaction of e-learning class. This study analysis variables reliability by Cronbach's Alpha test.

In general Cronbach's Alpha test used to evaluate how consistently correlate among these variables when there are multiple variables. Since the Cronbach's Alpha value represents the level of the correlation coefficient, it has a value between 0.0 and 1.0. The closer the coefficient value is to 1.0 , the more reliability is to perfect. The criterion that reliability is high or low generally believed to be item reliability when the Cronbach's Alpha coefficient is 0.6 or more. In this study, the reliability of the items tested by the basis of this criterion. In the study, the Cronbach's Alpha coefficient for each measurement variables that affects to the learning satisfaction is 0.854 for the learning content, 0.897 for the system, and 0.881 for the operational management. It can say that it has sufficient reliability since it is closer to 1.0 
than reliability standard of 0.6 . The results of the analysis shows in "Table III".

TABLE III: RELIABILITY ANALYSIS OF LEARNING SATISFACTION ITEMS

\begin{tabular}{|c|c|c|c|c|c|c|}
\hline \multirow{2}{*}{ domain } & \multirow{2}{*}{$\underset{\text { tools }}{\text { Measuring }}$} & \multirow{2}{*}{$\begin{array}{c}\text { Cronbach } \\
\text { 's } \\
\text { Alpha }\end{array}$} & \multicolumn{4}{|c|}{ statistic } \\
\hline & & & $\begin{array}{c}\text { Variable } \\
\text { name }\end{array}$ & Average & $\begin{array}{l}\text { Standard } \\
\text { Deviation }\end{array}$ & $N$ \\
\hline \multirow{14}{*}{$\begin{array}{c}\text { Learning } \\
\text { satisfaction }\end{array}$} & \multirow{5}{*}{$\begin{array}{l}\text { Learning } \\
\text { contents }\end{array}$} & \multirow{5}{*}{0.854} & $\mathrm{C} 1$ & 4.04 & 0.999 & 72 \\
\hline & & & $\mathrm{C} 2$ & 4.04 & 0.795 & 72 \\
\hline & & & $\mathrm{C} 3$ & 3.90 & 1.009 & 72 \\
\hline & & & $\mathrm{C} 4$ & 3.88 & 1.198 & 72 \\
\hline & & & $\mathrm{C} 5$ & 3.74 & 1.113 & 72 \\
\hline & \multirow{4}{*}{ system } & \multirow{4}{*}{0.897} & $\mathrm{~S} 1$ & 4.24 & 1.041 & 72 \\
\hline & & & $\mathrm{S} 2$ & 3.99 & 0.896 & 72 \\
\hline & & & S3 & 4.00 & 0.934 & 72 \\
\hline & & & $\mathrm{S} 4$ & 4.17 & 0.872 & 72 \\
\hline & \multirow{5}{*}{$\begin{array}{c}\text { Operations } \\
\text { Management }\end{array}$} & \multirow{5}{*}{0.881} & M1 & 4.04 & 0.956 & 72 \\
\hline & & & M2 & 3.93 & 0.954 & 72 \\
\hline & & & M3 & 4.00 & 0.934 & 72 \\
\hline & & & M4 & 3.83 & 1.101 & 72 \\
\hline & & & M5 & 3.43 & 1.185 & 72 \\
\hline
\end{tabular}

\section{2) Dependent variable reliability test}

The Cronbach's Alpha coefficient for each measurement variables that affects to the job utilization, which is a dependent variable, is 0.908 for business connection, 0.881 for accident prevention, 0.876 for safety guidance, and 0.885 for consciousness change. As a result, the internal validity of the questionnaire can verify because the questionnaire consists of the items based on the previous studies. The external validity can secure through the reliability coefficient test. The results of the analysis shows in Table IV".

TABLE IV: RELIABILITY ANALYSIS OF JOB UTILIZATION ITEMS

\begin{tabular}{|c|c|c|c|c|c|c|}
\hline \multirow[b]{2}{*}{ domain } & \multirow{2}{*}{$\underset{\text { Measuring }}{\text { Meols }}$} & \multirow{2}{*}{$\begin{array}{c}\text { Cronbach's } \\
\text { Alpha }\end{array}$} & \multicolumn{4}{|c|}{ statistic } \\
\hline & & & $\begin{array}{c}\text { Variable } \\
\text { name }\end{array}$ & Average & $\begin{array}{l}\text { Standard } \\
\text { Deviation }\end{array}$ & $\mathbf{N}$ \\
\hline \multirow{10}{*}{$\begin{array}{c}\text { Business } \\
\text { utilization }\end{array}$} & \multirow{2}{*}{$\begin{array}{c}\text { Business } \\
\text { Connectivity }\end{array}$} & \multirow{2}{*}{0.908} & L1 & 4.04 & 0.926 & 72 \\
\hline & & & L2 & 3.94 & 0.918 & 72 \\
\hline & \multirow{6}{*}{$\begin{array}{l}\text { Prevention of } \\
\text { accidents }\end{array}$} & \multirow{6}{*}{0.881} & $\mathrm{P} 1$ & 3.96 & 1.156 & 72 \\
\hline & & & $\mathrm{P} 2$ & 3.75 & 1.045 & 72 \\
\hline & & & P3 & 4.10 & 0.891 & 72 \\
\hline & & & $\mathrm{P} 4$ & 4.31 & 0.944 & 72 \\
\hline & & & P5 & 4.21 & 0.855 & 72 \\
\hline & & & P6 & 4.17 & 0.934 & 72 \\
\hline & Safety map & 0.876 & P7 & 3.78 & 1.064 & 72 \\
\hline & $\begin{array}{c}\text { Safety } \\
\text { consciousness } \\
\text { change }\end{array}$ & 0.885 & $\mathrm{R} 1$ & 4.13 & 0.817 & 72 \\
\hline
\end{tabular}

\section{Differences in Learning Satisfaction and Job \\ Utilization According to General Characteristics}

The results of this study are as follows. First, the general teachers more interested in safety education than the teachers of other job area. It means teacher who is related with students should have responsibility for school safety. The higher the age of the learner, the more concern about safety. The results of this study are as follows.

\section{1) Differences in learning satisfaction and job utilization by age}

A method of testing the statistical significance of the mean difference between two or more groups use ANOVA (Variance Analysis). This study analyze the difference of learning satisfaction and work utilization according to the age of subjects. The formula for deriving the average value of each item is as follows.

$$
\begin{aligned}
& C=(C 1+C 2+C 3+C 4+C 5) / 5 \\
& S=(S 1+S 2+S 3+S 4) / 4 \\
& M=(M 1+M 2+M 3+M 4+M 5) / 5 \\
& L=(L 1+L 2) / 2 \\
& P=(P 1+P 2+P 3+P 4+P 5+P 6+P 7) / 7 \\
& R=R 1
\end{aligned}
$$

At the significance level $p>0.1$, result of ANOVA test of null hypothesis can adopt as the test statistic value, because there are no significant statistics result values. Therefore, the learning satisfaction and the work utilization degree according to the age cannot be meaningful. The results shows in "Table V".

TABLE V: DIFFERENCES IN LEARNING SATISFACTION AND WORK USE BY AGE

\begin{tabular}{c|c|c|c|c|c}
\hline \hline \multicolumn{3}{c}{ Variable name } & DF & $\boldsymbol{F}$ Value & $\boldsymbol{P r}>\boldsymbol{F}$ \\
\hline \multirow{4}{*}{$\begin{array}{c}\text { Learning } \\
\text { satisfaction }\end{array}$} & Learning contents & $\mathrm{C}$ & 3,68 & 0.25 & $\mathbf{0 . 8 6 2}$ \\
\cline { 2 - 6 } & system & $\mathrm{S}$ & 3,68 & 1.20 & $\mathbf{0 . 3 1 6}$ \\
\cline { 2 - 6 } & Operations Management & $\mathrm{M}$ & 3,68 & 1.19 & $\mathbf{0 . 3 1 9}$ \\
\hline \multirow{4}{*}{$\begin{array}{c}\text { Business } \\
\text { utilization }\end{array}$} & Business Connectivity & $\mathrm{L}$ & 3,68 & 0.29 & $\mathbf{0 . 8 3 2}$ \\
\cline { 2 - 6 } & Prevention of accidents & $\mathrm{P}$ & 3,68 & 0.45 & $\mathbf{0 . 7 1 6}$ \\
\cline { 2 - 6 } & $\begin{array}{c}\text { Safety consciousness } \\
\text { change }\end{array}$ & $\mathrm{R}$ & 3,68 & 0.79 & $\mathbf{0 . 5 0 6}$ \\
\hline \hline
\end{tabular}

Significant level: $p<0.1^{*}, p<0.05^{* *}, p<0.01^{* * *}$

\section{2) Difference between job satisfaction and work utilization according to job area}

For the testing of difference between job satisfaction and work utilization, statistical method of ANOVA used in order to analyze differences in learning satisfaction and job utilization according to job area.

The null hypothesis rejected and the hypothetical

\begin{tabular}{|c|c|c|c|c|c|}
\hline \multicolumn{3}{|c|}{ Variable name } & DF & $F$ Value & $\operatorname{Pr}>F$ \\
\hline \multirow{3}{*}{$\begin{array}{l}\text { Learning } \\
\text { satisfaction }\end{array}$} & Learning contents & $\mathrm{C}$ & 3,68 & 3.82 & $0.013 * *$ \\
\hline & system & $S$ & 3,68 & 3.27 & $0.026 * *$ \\
\hline & Operations Management & M & 3,68 & 1.55 & 0.208 \\
\hline \multirow{3}{*}{$\begin{array}{l}\text { Business } \\
\text { utilization }\end{array}$} & Business Connectivity & $\mathrm{L}$ & 3,68 & 1.41 & 0.248 \\
\hline & Prevention of accidents & $\mathrm{P}$ & 3,68 & 1.50 & 0.222 \\
\hline & $\begin{array}{l}\text { Safety consciousness } \\
\text { change }\end{array}$ & $\mathrm{R}$ & 3,68 & 1.23 & 0.305 \\
\hline
\end{tabular}
hypothesis can adopt at the significance level of $5 \%$. Therefore, learning satisfaction according to work area is meaningful.

TABLE VI: DIFFERENCES IN LEARNING SATISFACTION AND JOB UTILIZATION ACCORDING TO JOB TYPE

Significant level: $p<0.1^{*}, p<0.05^{* *}, p<0.01^{* * *}$

However, because of the significance level $p>0.1$, the null hypothesis can adopt for the operation management and job utilization according. The results shows in "Table VI". It means all of teachers have responsibility of safety education, 
but they could not use it their real school safety usage.

3) Difference in learning satisfaction and job utilization according to work experience

The ANOVA used to analyze differences in learning satisfaction and job utilization according to the work experience of the study subjects. The satisfaction level of learning satisfaction according to work experience is $p<0.01$, and the null hypothesis is rejected and the alternative hypothesis can be adopted at the level of safety inspections and safety consciousness change test statistic value of $5 \%$.

Therefore, prevention of accidents and change of safety consciousness of learning satisfaction and job utilization according to work experience are very meaningful for difference between two variables. However, because the null hypothesis can adopt because the value of the statistics according to the work experience is $\mathrm{p}>0.1$, it cannot be meaningful that the work relation according to the work experience. The results show in "Table VII".

TABLE VII: DIFFERENCES IN LEARNING SATISFACTION AND JOB UTILIZATION ACCORDING TO WORK EXPERIENCE

\begin{tabular}{|c|c|c|c|c|c|}
\hline \multicolumn{3}{|c|}{ Variable name } & DF & $F$ Value & $\operatorname{Pr}>F$ \\
\hline \multirow{3}{*}{$\begin{array}{c}\text { Learning } \\
\text { satisfactio } \\
n\end{array}$} & Learning contents & $\mathrm{C}$ & 3,68 & 4.94 & $0.003 * * *$ \\
\hline & system & S & 3,68 & 4.73 & $0.004 * * *$ \\
\hline & Operations Management & M & 3,68 & 6.20 & $0.000 * * *$ \\
\hline \multirow{3}{*}{$\begin{array}{l}\text { Business } \\
\text { utilization }\end{array}$} & Business Connectivity & $\mathrm{L}$ & 3,68 & 1.05 & 0.375 \\
\hline & Prevention of accidents & $\mathrm{P}$ & 3,68 & 3.30 & $0.025 * *$ \\
\hline & $\begin{array}{l}\text { Safety consciousness } \\
\text { change }\end{array}$ & $\mathrm{R}$ & 3,68 & 2.75 & $0.049 * *$ \\
\hline
\end{tabular}

Significant level: $p<0.1^{*}, p<0.05^{* *}, p<0.01^{* * *}$

\section{Analysis of Influence of Learning Satisfaction on Job Utilization}

In order to analyze the influence of learning satisfaction of e-learning based teacher safety education on job utilization, this study set up a regression model and test the model. We use the $\mathrm{t}$ test for each coefficient of the model, where the null hypothesis is H0: $\alpha=0$ and $\beta=0$. The $\mathrm{F}$ test is used to test the model itself, where the null hypothesis is H0: $\alpha=\beta=0$. The expected linear model shows in "Fig. 2".

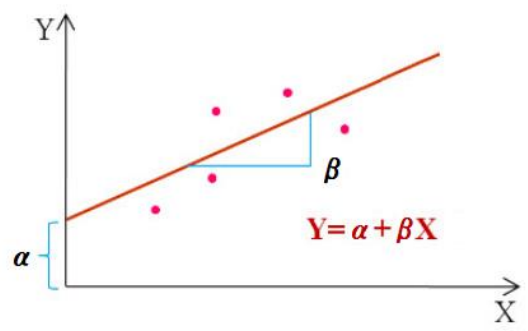

Fig. 2. Linear model.

\section{1) Analysis of the influence of learning satisfaction on business linkage}

A statistical technique for modeling and analyzing the relationship between dependent and independent variables using data obtained through surveys use regression model, and dependent variables can predict through several independent variables. This study analyze the influence of the learning satisfaction of the e-learning based teacher safety education on the job relatedness by regression analysis and derive the regression model as the average value of learning contents, system and operation management. Business connectivity estimates the regression equation based on the regression coefficient to predict the change of business connection after the e-learning based teacher training.

$$
L=1.08+0.74 C
$$

( $L$ : Business connectivity, $C$ : Learning contents)

$L=0.82+0.77 S(L:$ Business connectivity, $S:$ system $)$

$L=1.17+0.73 M$

( $L$ : Business connectivity, $M$ : Operations management)

In the statistical of the model, first, in the case of the $L=$ $1.08+0.74 C$ model, the t-value of each coefficient is 2.90 , 7.99 , so that the null hypothesis that the coefficient is zero at the significance level of 0.01 can be rejected. In addition, this study can reject the hypothesis that $\alpha=\beta=0$ for the existence of the null hypothesis model at a significance level of 0.01 and the $F$ value is 63.80 .

Second, in the case of the $L=0.82+0.77 \mathrm{~S}$ model, the $\mathrm{t}$-value of each coefficient is $2.20,8.66$. In addition, if this study examine the regression model, it can reject the hypothesis that $\alpha=\beta=0$ for the existence of the null hypothesis model at the significance level of 0.01 and the $F$ value is 75.05. Third, in the case of the $L=1.17+0.73 M$ model, the t-value of each coefficient is 3.39 and 8.29 , so that the null hypothesis that the coefficient is zero at the significance level of 0.01 can be rejected. In addition, if this study examine the regression model, it can reject the hypothesis that $\alpha=\beta=0$ for significance level of 0.01 and the $F$ value is 68.76 . The results show in Table VIII".

TABLE VIII: INFLUENCE OF LEARNING SATISFACTION ON BUSINESS CONNECTIVITY

\begin{tabular}{|c|c|c|c|c|}
\hline Linear model & & & Test sta & \\
\hline \multirow{5}{*}{$L=1.08+0.74 C$} & \multirow{3}{*}{$t$-test } & DF & t Value & $\operatorname{Pr}>|t|$ \\
\hline & & 1 & 2.90 & $0.005^{* * * *}$ \\
\hline & & 1 & 7.99 & $0.000 * * *$ \\
\hline & \multirow{2}{*}{$F$-test } & DF & F Value & $\operatorname{Pr}>F$ \\
\hline & & 1,70 & 63.80 & $0.000 * * *$ \\
\hline \multirow{5}{*}{$L=0.82+0.77 S$} & \multirow{3}{*}{$t$-test } & DF & t Value & $\operatorname{Pr}>|t|$ \\
\hline & & 1 & 2.20 & $0.031 * *$ \\
\hline & & 1 & 8.66 & $0.000 * * *$ \\
\hline & \multirow{2}{*}{$F$-test } & DF & F Value & $\operatorname{Pr}>\mathrm{F}$ \\
\hline & & 1,70 & 75.05 & $0.000 * * *$ \\
\hline \multirow{5}{*}{$L=1.17+0.73 M$} & \multirow{3}{*}{$t$-test } & DF & t Value & $\operatorname{Pr}>|t|$ \\
\hline & & 1 & 3.39 & $0.001 * * *$ \\
\hline & & 1 & 8.29 & $0.000 * * *$ \\
\hline & \multirow{2}{*}{$F$-test } & DF & F Value & $\operatorname{Pr}>\mathrm{F}$ \\
\hline & & 1,70 & 68.76 & $0.000 * * *$ \\
\hline
\end{tabular}

Significant level: $p<0.1^{*}, p<0.05^{* *}, p<0.01 * * *$

\section{2) Analysis of influence of learning satisfaction on accident prevention}

Regression analysis used to analyze the impact of learning satisfaction on safety education on e-learning based teacher 
safety education. Regression analysis used to predict learning satisfaction as the mean value of learning contents, system, and operation management. Accident Prevention estimates the regression equation based on the regression coefficient to predict changes in the prevention of safety accidents after e-learning safety education based on the teacher.

$P=1.41+0.67 C$

( $P$ : Prevention of accidents, $C$ : Learning contents)

$P=1.20+0.69 \mathrm{~S}$ ( $P$ : Prevention of accidents, $S:$ system $)$

$P=1.53+0.65 M$

( $P$ : Prevention of accidents, M: Operations Management) In the statistical test of this model, First, in the case of the $P=1.41+0.67 C$ model, the $t$-value of each coefficient is 4.67 and 8.89 , so that the null hypothesis that the coefficient is zero at the significance level of 0.01 can be rejected. In addition, if this study examine the regression model, it can reject the hypothesis that $\alpha=\beta=0$ for the existence of the null hypothesis model at the significance level of 0.01 and the $F$ value of 78.95 .

Second, in the case of the $P=1.20+0.69 S$ model, the $\mathrm{t}$-value of each coefficient is 3.97 and 9.49 , which means that the null hypothesis that the coefficient is zero at the significance level of 0.01 can be rejected. In addition, if this study examine the regression model, it can reject the hypothesis that $\alpha=\beta=0$ for the existence of the null hypothesis model at the significance level of 0.01 and the $F$ value is 90.11 . Third, in the case of the $P=1.53+0.65 M$ model, the $t$-value of each coefficient is 5.38 and 8.97 , so that the null hypothesis that the coefficient is zero at the significance level of 0.01 can be rejected. In addition, if we examine the regression model, we can reject the hypothesis that $\alpha=\beta=0$ at the significance level of 0.01 and the $\mathrm{F}$ value is 80.53 . The results shows in "Table IX".

TABLE IX: INFLUENCE OF LEARNING SATISFACTION ON SAFETY ACCIDENT PREVENTION

\begin{tabular}{|c|c|c|c|c|}
\hline Linear model & & & Test sta & \\
\hline \multirow{5}{*}{$P=1.41+0.67 C$} & \multirow{3}{*}{$t$-test } & DF & $t$ Value & $\operatorname{Pr}>|t|$ \\
\hline & & 1 & 4.67 & $0.000 * * *$ \\
\hline & & 1 & 8.89 & $0.000 * * *$ \\
\hline & \multirow{2}{*}{$F$-test } & DF & $F$ Value & $P r>F$ \\
\hline & & 1,70 & 78.95 & 0.000 **** \\
\hline \multirow{5}{*}{$P=1.20+0.69 S$} & \multirow{3}{*}{$t$-test } & $\mathrm{DF}$ & $t$ Value & $\operatorname{Pr}>|t|$ \\
\hline & & 1 & 3.97 & $0.000 * * *$ \\
\hline & & 1 & 9.49 & $0.000 * * *$ \\
\hline & \multirow{2}{*}{$F$-test } & DF & $F$ Value & $\operatorname{Pr}>F$ \\
\hline & & 1,70 & 90.11 & $0.000 * * *$ \\
\hline \multirow{5}{*}{$P=1.53+0.65 M$} & \multirow{3}{*}{$t$-test } & $\mathrm{DF}$ & $t$ Value & $\operatorname{Pr}>|t|$ \\
\hline & & 1 & 5.38 & $0.000 * * *$ \\
\hline & & 1 & 8.97 & $0.000 * * *$ \\
\hline & \multirow{2}{*}{$F$-test } & $\mathrm{DF}$ & $F$ Value & $\operatorname{Pr}>F$ \\
\hline & & 1,70 & 80.53 & $0.000 * * *$ \\
\hline
\end{tabular}

Significant level: $p<0.1^{*}, p<0.05^{* *}, p<0.01^{* * *}$

3) Analysis of influence of learning satisfaction on safety consciousness change

Regression analysis used to analyze the influence of learning satisfaction on safety consciousness of e-learning based teacher safety education. Regression analysis used to predict learning satisfaction as the mean value of learning contents, system, and operation management. Safety consciousness change estimates regression equations based on regression coefficients to predict changes in safety consciousness after e-learning class.

$R=1.29+0.72 C$

( $R$ : Safety consciousness change, $C$ : Learning contents)

$R=1.77+0.57 S(S:$ system $)$

$R=2.27+0.48 M(M$ : Operations Management $)$

In the statistical test of this model, first, in the case of the $R$ $=1.29+0.72 C$ model, the $\mathrm{t}$-value of each coefficient is 3.86 and 8.64 , so that the null hypothesis that the coefficient is zero at the significance level of 0.01 can be rejected. In addition, if we examine the regression model, we can reject the hypothesis that $\alpha=\beta=0$ at the significance level of 0.01 and the $F$ value of 74.66 .

Second, in the case of the $R=1.77+0.57 S$ model, the $\mathrm{t}$-value of each coefficient is 4.29 and 5.83, and the coefficient is zero. In the regression model, the $\mathrm{F}$ value is 33.99 and the hypothesis that $\alpha=\beta=0$ for the null hypothesis model is rejected at the significance level of 0.01 .

Third, in the case of the $R=2.27+0.48 M$ model, the $t$-value of each coefficient is 5.72 and 4.78 , so that the null hypothesis that the coefficient is zero at the significance level of 0.01 can be rejected. In addition, if this study testify the regression model, it can reject the hypothesis that $\alpha=\beta=0$ for the existence of the null hypothesis model at the significance level of 0.01 and the $F$ value of 22.82. The results shows in "Table X".

TABLE X: INFLUENCE OF LEARNING SATISFACTION ON SAFETY CONSCIOUSNESS CHANGE

\begin{tabular}{|c|c|c|c|c|}
\hline Linear model & \multicolumn{4}{|c|}{ Test statistic } \\
\hline \multirow{5}{*}{$R=1.29+0.72 C$} & \multirow{3}{*}{$t$-test } & $\mathrm{DF}$ & $t$ Value & $\operatorname{Pr}>|t|$ \\
\hline & & 1 & 3.86 & $0.000 * * *$ \\
\hline & & 1 & 8.64 & $0.000 * * *$ \\
\hline & \multirow{2}{*}{$F$-test } & DF & $F$ Value & $\operatorname{Pr}>F$ \\
\hline & & 1,70 & 74.66 & $0.000 * * *$ \\
\hline \multirow{5}{*}{$R=1.77+0.57 S$} & \multirow{3}{*}{$t$-test } & $\mathrm{DF}$ & $t$ Value & $\operatorname{Pr}>|t|$ \\
\hline & & 1 & 4.29 & $0.000 * * * *$ \\
\hline & & 1 & 5.83 & $0.000 * * *$ \\
\hline & \multirow[b]{2}{*}{$F$-test } & $\mathrm{DF}$ & $F$ Value & $\operatorname{Pr}>F$ \\
\hline & & 1,70 & 33.99 & $0.000 * * *$ \\
\hline \multirow{5}{*}{$R=2.27+0.48 M$} & \multirow{3}{*}{$t$-test } & $\mathrm{DF}$ & $t$ Value & $\operatorname{Pr}>|t|$ \\
\hline & & 1 & 5.72 & $0.000 * * *$ \\
\hline & & 1 & 4.78 & $0.000 * * *$ \\
\hline & \multirow[b]{2}{*}{$F$-test } & $\mathrm{DF}$ & $F$ Value & $\operatorname{Pr}>F$ \\
\hline & & 1,70 & 22.82 & $0.000 * * *$ \\
\hline
\end{tabular}

Significant level: $p<0.1^{*}, p<0.05^{* *}, p<0.01 * * *$ 


\section{CONCLUSIONS AND RECOMMENDATIONS}

Teachers of schools and educational institutions should be educated actively not only as a legal obligation but also as an opportunity to improve the practical life and effective utilization of work for the safety of the teachers themselves. In addition, it should pay attention to measurement of educational performance about post-training utilization. In addition to the implementation of teacher safety education, it is necessary to strengthen the recognition of the importance of the performance and efficiency of the teacher safety education in the future.

The purpose of this study is to investigate the learning satisfaction of the e-learning based teacher safety education and analyze the satisfaction of the learning and the utilization of the work to see whether the satisfaction after the education affects the actual utilization of the work. The variables related to learning satisfaction are set as learning contents, system, and operation management. The variables related to work utilization are set as work connection, accident prevention, safety guidance, and safety consciousness change. The experimental group of the study are 72 students from Gyeonggi Provincial Office of Education who responded to the questionnaire. The results analyzed and the following conclusions obtained.

First, there is no difference in learning satisfaction and work utilization according to age in the e-learning based safety training for teachers. Second, there is no difference in learning satisfaction according to work area, but there is a difference in work utilization. Third, there is a difference in learning satisfaction and work utilization according to work experience. Fourth, learning satisfaction of e-learning based teacher safety education affects the utilization of work.

The results of this study have the following limitations. First, the questionnaires collected in this study targeted to teachers of the Gyeonggi Provincial Office of Education. Second, 'Satisfaction' among the questionnaires of this study is limited to the general satisfaction survey because it write not for the lecture of the specific site but for the individual learning experiences of the respondents.

It is necessary to develop more specific and systematic safety education programs and curriculum in order to improve the quality level and learning satisfaction of e-learning-based teacher safety education and to utilize effective work. In addition, there is a difference between the satisfaction of learning and the utilization of work according to the work area and work experience of teachers. Therefore, various and detailed programs should be developed and continuously provided. In the future, it will be necessary to expand the research viewpoint so that the evaluation of learning satisfaction and the change of the work utilization through the comparison of the group education of the teacher safety education and the distance education.

Most teachers meet and learn the lecture through remote online training, and students need to provide hands-on safety education. The safety education for the teacher responsible for the safety education of the students should also include the hands-on experience and hands-on practice contents in detail.

\section{CONFLICT OF INTEREST}

The authors declare no conflict of interest.

\section{AUTHOR CONTRIBUTIONS}

Mi Hwa Song conducted the research; Tae In Han suggested research methodology and perform statistical data analysis as a correspondence author; Mi Hwa Song and Tae In Han also wrote the paper together, all authors had approved the final version.

\section{REFERENCES}

[1] I.-J. Kim, "Child care facility safety education. An empirical study on the actual conditions of safety accidents and the teachers' safety education scope and method recognition," Journal of the Korean Society for Safety Management, vol. 14, no. 4, pp. 125-136, 2012.

[2] 2018 Guidance on Completion of Safety Education for Staff of Gyeonggi Provincial Office of Education, 2018.

[3] Y. J. Jeong, "The structural relationship between mobile learning system quality, information quality, service quality, personal innovation orientation, system usage level, and learner satisfaction," Journal of the Korea Contents Association, vol. 14, pp. 477-490, 2014.

[4] E.-A. Cho, "Analysis of the structural relationship between task value, e-learning quality, learning approach, satisfaction and academic achievement in cyber lectures," 2015.

[5] J.-Y. Lee, and E.-J. Lee, "The effect of system, information and service quality on learner satisfaction in university e-learning," Educational Science Research, vol. 41, no. 3, pp. 119-147, 2010.

[6] M.-B. Lee and J.-W. Kim, "An exploratory study on success factors of e-learning system," Information Systems Research, vol. 15, no. 4, pp. 171-188, 2006.

[7] P. Y. Tae, "An empirical study on factors affecting learning experience and loyalty of e-learning learners," Management Research, vol. 27, pp. 75-98, 2012.

[8] C.-H. Park and K. K. Lee, "An empirical study on the quality and satisfaction of e-learning service, revisiting and recommendation intention," Productivity Review (Old Productivity Research), vol. 26, no. 2, pp. 325-354, 2012.

[9] W. H. DeLone and E. R. McLean, "The DeLone and McLean model of information system success: A ten-year update," Journal of Management Information System, vol. 19, no. 4, pp. 9-30, 2003

[10] K. A. Choi, "Web-based maintenance education learning satisfaction and job performance self-evaluation analysis," Master thesis, Korea National Open University, 2015.

[11] K. Y. Seok and Y. Y. Kim, "A study on the contents composition of safety education for school administrative staff," Learner-Centered Curriculum Education, vol. 16, pp. 239-258, 2016.

[12] Y.-K. Lee, "Relationship analysis of e-learning service quality, satisfaction, reuse intention," Master's thesis, Sogang University, 2012.

[13] Y.S. Wang, H.-Y. Wang, and D. Y. Shee, "Measuring e-learningsystems success in an organizational context: Scale developmentand validation," Computer in Human Behavior, vol. 23, pp. 1792-1808, 2007.

[14] Y.-S. Hong et al., "Factors influencing child care teachers' safety performance," Journal of Nursing Education, vol. 13, no. 1, pp. 66-73, 2007.

[15] C. M. Chiu, C. S. Chiu, and H. C. Chang, "Examining the integrated influence of fairness and quality on learners' satisfaction and Web based learning continuance intention," Information Systems Journal, vol. 17, no. 3, pp. 271-287, 2007.

[16] D. B. Buller, M. K. Buller, and I. Kane, "Web-based strategies to disseminate a sun safety curriculum to public elementary schools and state-licensed child-care facilities," Health Psychology, 2005.

[17] I. Jung, S. Choi, C. Lim, and J. Leem, "Effects of different types of interaction on learning achievement, satisfaction and participation in web-based instruction," Innovations in Education and Teaching Internationa, 2002.

[18] O. C. Kirton, "Measuring service-specific performance and educational value within a general surgery residency: The power of a prospective, anonymous, Web-based rotation evaluation system in the optimization of resident satisfaction," Surgery, 2001.

Copyright (C) 2019 by the authors. This is an open access article distributed under the Creative Commons Attribution License which permits unrestricted use, distribution, and reproduction in any medium, provided the original work is properly cited (CC BY 4.0). 


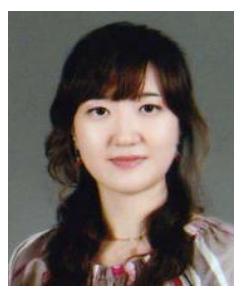

Mi Hwa Song was born on Aug 11, 1975 at Seoul, Korea. She graduated from Seoul Cyber University at Seoul, and her major is multimedia design. She graduated from the Graduate School of Korea National Open University, at the same time she works as a management staff at the Balgok Elementary Public School in Uijeongbu city of Gyeonggi province. She is interested in digital literacy, e-learning, distance learning, learning analytics and big data.

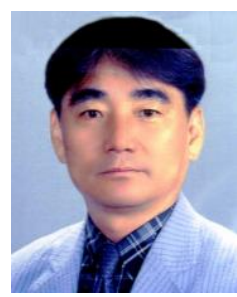

Tea In Han was born on May 19, 1955 at Seoul, Korea. He graduated from Korea University for the M.A and B.A. He is Ph.D. at Korea University in 1999. His major is $\mathrm{AI}$ of computer science. He is professor of e-Learning department of Korea National Open University. And he has responsibilities of e-learning standardization and policy for MoE(Ministry of Education), MoCIT(Ministry of Commerce, Industry and Trade), and KATS (Korea Agency of Technology and Standardization). He is interested in e-learning, deep learning, distance learning, and learning analytics. 